\title{
Saline agriculture in Mediterranean environments
}

\author{
Albino Maggio, Stefania De Pascale, Massimo Fagnano, Giancarlo Barbieri \\ Dipartimento di Ingegneria Agraria e Agronomia del Territorio, Università di Napoli Federico Il, Italy
}

\begin{abstract}
Salinization is increasingly affecting world's agricultural land causing serious yield loss and soil degradation. Understanding how we could improve crop productivity in salinized environments is therefore critical to meet the challenging goal of feeding 9.3 billion people by 2050. Our comprehension of fundamental physiological mechanisms in plant salt stress adaptation has greatly advanced over the last decades. However, many of these mechanisms have been linked to salt tolerance in simplified experimental systems whereas they have been rarely functionally proven in real agricultural contexts. In-depth analyses of specific crop-salinity interactions could reveal important aspects of plant salt stress adaptation as well as novel physiological/agronomic targets to improve salinity tolerance. These include the developmental role of root $v s$. shoot systems respect to water-ion homeostasis, morphological vs. metabolic contributions to stress adaptation, developmental processes $v s$. seasonal soil salinity evolution, residual effects of saline irrigation in non-irrigated crops, critical parameters of salt tolerance in soil-less systems and controlled environments, response to multiple stresses. Finally, beneficial effects of salinization on qualitative parameters such as stress-induced accumulation of high nutritional value secondary metabolites should be considered, also. In this short review we attempted to highlight the multifaceted nature of salinity in Mediterranean agricultural systems by summarizing most experimental activity carried out at the Department of Agricultural Engineering and Agronomy of University of Naples Federico II in the last few years.
\end{abstract}

Correspondence: Dr. Albino Maggio, Dipartimento di Ingegneria Agraria e Agronomia del Territorio, Università di Napoli Federico II, via Università 100, 80055 Portici (NA), Italy.

Tel. +39.081.2539133 - Fax: +39.081 .5512977 .

E-mail: almaggio@unina.it

Key words: salt stress, vegetable crops, field crops.

Received for publication: 11 October 2010.

Accepted for publication: 3 December 2010.

(c) Copyright A. Maggio et al., 2011

Licensee PAGEPress, Italy

Italian Journal of Agronomy 2011; 6:e7

doi:10.4081/ija.2011.e7

This article is distributed under the terms of the Creative Commons Attribution Noncommercial License (by-nc 3.0) which permits any noncommercial use, distribution, and reproduction in any medium, provided the original author(s) and source are credited.

\section{Introduction}

Salinity is one of the major environmental constraints that limit crop productivity and quality. The United Nations Food and Agriculture Organization estimated that approximately $20 \%$ of irrigated lands is affected by increasing salinity (Rozema and Flowers, 2008). The competition for fresh water in agricultural, domestic and industrial uses, mainly due to the growing population and climate changes, is further contributing to salinization (United Nations, 2009). Arid and semiarid regions are more exposed to this phenomenon since in these climatic zones high evapotranspiration rates, irrigation and reduced rainfall all concur to salt accumulation in the uppermost soil layers, where root development mostly occurs (Munns, 2005). Salinization does not pertain only to extreme environments and/or southern regions of the world, however. In Europe, 26 countries have reported cases of salinization with higher frequency in Mediterranean coastal areas (Flowers, 2004). Although soil salinization could be delayed through proper irrigation management (Rhoades et al., 1992) it cannot be avoided. Consequently, the progression of salinization is increasingly jeopardizing productions of irrigated lands, the most active agricultural areas of the world (Royal Society, 2009).

\section{Historical background}

In order to identify proper strategies to improve agricultural management in salinized areas it is essential to understand how salinity develops in the soil and how plants react to salt stress. The effects of salinization on agricultural crops have been discussed in a vast body of literature (Hasegawa et al., 2000) although in early years, inhomogeneous experimental conditions, unknown species-specific variability and insufficiently developed experimental techniques have somehow hindered progress in this field. In order to compare salinity tolerance in different plant species, standardization criteria were introduced by Maas and Hoffman (1977) who described the response of glycophytes to salinity by plotting the relative yield as a continuous function of root zone salinity. Based on this model, it was possible to categorize different species respect to two specific parameters, namely the tolerance threshold (i.e. the maximum soil salinity that does not reduce yield below that obtained under non-saline conditions) and the slope (i.e. the rate of yield decay beyond the tolerance threshold). Although the classification of Maas and Hoffman was mostly intended to provide a practical guideline in terms of crop choice and water management in saline agriculture (Rhoades et al., 1992), it also pointed to different physiological bases that could determine variable responses to salinity. This was an important step towards the comprehension of the fundamental biology of plant salt tolerance.

The Maas-Hoffman model was proven to be quite useful for a firstlevel ranking of crop salt tolerance (Maas and Hoffman, 1977; Maas and Grattan, 1999). However it turned out to be rather unstable respect to environmental factors that could interact with and affect general growth and/or plant responses to salinity. Plant exposure to different root-zone temperatures (Dalton et al., 1997), solar radiation (Dalton et 
al., 2001) and aerial $\mathrm{CO}_{2}$ levels (Maggio et al., 2002) may affect both threshold and slope of the Maas-Hoffman salt response curve and consequently weaken the comparative purpose of this model. It was specifically argued that a simple relationship between relative yield and root zone salinity could not uncouple general plant growth responses from specific salt tolerance properties (Dalton et al., 2000). These observations pointed to the need of identifying new indexes that were more stable to environmental variables and eventually shed some light on the intrinsic physiological basis of plant salt tolerance. The salinity stress index (SSI) proposed by Frank Dalton and collaborators (Dalton et al., 1997) complied with these requirements. The SSI also identified a threshold-slope behavior of the plant response function to salinity, yet it was at the same time an environmentally invariant measure of plant salt tolerance because it integrated biochemical and variable physical parameters in the soil-plant-air continuum, which control salt loading to the shoot and simultaneously affect transpiration and growth (Dalton et al., 2000).

Subsequently, the water day stress index (WDSI) has also been proposed to assess plant response to salinity and further elucidate the complex relationship between plant water requirements and stress adaptation at whole-plant level (Katerji et al., 2000).

A major breakthrough towards standardization in salinity research has been the introduction of plant model systems that allowed us to link the extensive number of observations on the physiology of plant salt tolerance to a genetic basis (Zhu, 2000; Pardo, 2010). In the last 20 years, the use of Arabidopsis and, more recently, Arabidopsis relative model systems (Inan et al., 2004; Orsini et al., 2010b) has considerably contributed to improve our understanding of the fundamental molecular and physiological mechanisms in plant salt stress adaptation (Zhu, 2002).

We know today that the genetic variation defining different tolerance levels controls four major physiological processes: i) water/ion homeostasis; ii) hormone regulation and metabolic adjustment; iii) growth control and iv) injury control (Bressan et al., 2009). Genes involved in critical steps of these four processes have been isolated and transferred via genetic engineering to improve plant stress tolerance (Chinnusamy et al., 2005). Despite the polygenic nature of salinity and abiotic-stress tolerance in general, it has been demonstrated that salt tolerance can be improved by single-gene manipulation. Overexpression of SOS1- (Shi et al., 2003) and NHX1- (Zhang and Blumwald, 2001; Zhang et al., 2001), two genes involved in the control of $\mathrm{Na}^{+}$homeostasis, has allowed plant growth and flowering at $200 \mathrm{mM}$ $\mathrm{NaCl}$, a concentration that would be lethal for most cultivated crops. Additional targets for improving salt stress tolerance through genetic engineering include osmolytes overproduction (Karakas et al., 1997; Sheveleva et al., 1997; Sakamoto et al., 1998), potentiating the antioxidant system (Samis et al., 2002) and overexpression of transcription factors that could confer resistance to multiple abiotic stresses by simultaneous activation of several stress tolerance genes (Kasuga et al., 1999). Single-gene control of stress tolerance mechanisms was also demonstrated in Thellungiella halophila (salt cress), a halophytic Arabidopsis relative model system (Inan et al., 2004). Ethane-methylsulfonate (EMS) mutagenesis of salt cress seeds, followed by screening for reduced salinity tolerance, resulted in the isolation of putative mutants with loss of extreme tolerance, which behaved similarly to the glycophytic Arabidopsis thaliana (Inan et al., 2004).

Although the experimental results obtained so far are encouraging and have laid solid ground for stable crop salt tolerance improvements, the number of transgenic crops that have undergone to field trials is to date rather small (Xue et al., 2004). Major advancements can be expected upon identification of more efficient alleles of candidate genes (Quintero et al., 2002; Maggio et al., 2006), genetic engineering of newly identified components, combinations that would potentiate more than one above mentioned critical physiological mechanisms and iden- tification of novel control mechanisms (Chinnusamy and Zhu, 2009).

The possibility of using halophytes as potential crops for extreme environments has been reconsidered also in light of recent advancement in molecular techniques that may accelerate the selection of halophytic species that could best adapt to productive cultural systems (Rozema and Flowers, 2008).

It is unquestionable that the elucidation of fundamental molecular and physiological responses to salinity is instrumental to improving crops salt tolerance. Nevertheless, there has been little effort to frame these responses into specific cultural scenarios (Maggio et al., 2003a). In Mediterranean areas, the diversity of agricultural systems underlies the existence of different salinities that may have quite diverse effects on crop yield and quality. The Department of Agricultural Engineering and Agronomy at the University of Naples Federico II has been engaged since 1988 (Barbieri et al., 1994) in a long-term research activity aimed at elucidating the complexity of crop-salinity interactions in specific agricultural contexts. In the following, we attempted to summarize some of the results achieved so far and to highlight future research needs.

\section{Short- and long-term salinization}

Often overlooked have been the differences between short-term/temporary effects of salinization vs. long-term effects, the latter referred either to single irrigation seasons or multiple years. Summer irrigation of vegetable crops may cause variable salinization of the root zone that will dynamically evolve throughout the growing season. The magnitude of the damage to the crop will depend on the coincidence between salt toxicity levels and sensitivity of specific phenological stages to salt stress (Lutts et al., 1995; Hasegawa et al., 2000). Seasonal/temporary salinization can be partially controlled by fulfilling appropriate leaching requirements (Rhoades et al., 1992). However, at advanced salinization, permanent modifications of the soil physical-chemical properties will occur (Katerji et al., 1992; De Pascale et al., 2003c). These will further damage normal plant growth and consequently crop yield/quality. In Mediterranean areas, residual salinity and salinity-induced soil deterioration may affect both irrigated spring/summer crops and nonirrigated winter crops if autumn/winter rainfall is insufficient to counteract summer salinization by leaching the toxic ions below the root zone (De Pascale and Barbieri, 1997; De Pascale et al., 2005). Repeated irrigation with salinized water, associated with reduced winter rainfall, may lead to a substantial modification of the soil properties. Salinized soils often have higher water content because of a reduced water uptake, transpiration and development of salt stressed plants as well as reduced soil permeability due to the formation of surface seals (Rhoades et al., 1992; De Pascale and Barbieri, 1995). In the experimental field at the University of Naples Federico II Agronomy farm (latitude $43 \circ 31 \_\mathrm{N}$; longitude $14 \circ 58 \_$E), a clay-loam soil (42\% sand, $27 \%$ silt, $31 \%$ clay, trace amounts of lime) that had been irrigated with $1 \%$ $\mathrm{w} / \mathrm{v} \mathrm{NaCl}(171 \mathrm{mM})$ for ten years presented typical characteristics of alkaline-saline soils with decreased structure index, high water content, poor root zone aeration, surface crusting, $\mathrm{pH} \geq 8.0$ and remarkably reduced water infiltration rate $\left(12 \mathrm{~mm} \mathrm{~h}^{-1}\right.$ in non salinized control plots vs. $1 \mathrm{~mm} \mathrm{~h}^{-1}$ in soil irrigated with $1 \% \mathrm{NaCl}$ ). This was mostly associated to prevalence of sodium on the adsorption complex, which causes deflocculation of the clay particles and consequent reduction of soil permeability (Hachicha et al., 2000; De Pascale et al., 2005). In spite of $\mathrm{EC}_{\mathrm{e}}$ fluctuations during the year (high EC in summer and low $\mathrm{EC}$ in winter), monitoring of the winter soil EC has revealed a yearly linear increase of $0.46 \mathrm{dS} \mathrm{m}^{-1}$ over a 10-year period up to an EC of 6.1 $\mathrm{dS} \mathrm{m}{ }^{-1}$, indicating that the fall-winter rainfall was insufficient to contain salt accumulation caused by $1 \% \mathrm{NaCl}$ summer irrigation (De Pascale and Barbieri, 2000).

Short- and long term-responses should also be considered within 
each growing season. In Mediterranean areas, salt stress typically overlaps with midday water stress, which is experienced when plant transpirational rates are unable to cope with high VPDs. In these conditions, crops have to overcome both daily exposure to hyperosmotic stress and seasonal effects due to salt accumulation in the root-zone (Maggio et al., 2004). In tomato, we have highlighted different physiological responses to short- and long-term stress adaptation. Indeed plants that were more efficient in diurnal/daily osmotic adjustment did not perform as well, in terms of osmotically adjustment, over the entire growth season (Maggio et al., 2004). To date, it is still unclear which physiological mechanism is most critical respect to specific phenological stages and crop yield. This is not a trivial issue since physiological and metabolic adaptation mechanisms that may have an important function at certain developmental stage may be less effective in others (Sakamoto and Murata, 2002). When salinization occurs as seasonal phenomenon (i.e. summer irrigation for horticultural crops) critical salinity levels may be reached in proximity of fruit onset (tomato). At this stage, mechanisms of ion re-translocation/accumulation in older leaves may be more effective than ion compartmentation and/or exclusion for coping with an excessive tissue concentration of toxic ions (Pardossi et al., 1998; Maggio et al., 2005). Higher $\mathrm{Na}^{+}$accumulation in older leaves of salinized plants has been observed and functionally linked to a specific stress adaptation program (Amzallag, 2002; Zhu, 2002; Zhang and Blumwald, 2001). The activation of specific stress protection mechanisms respect to the developmental/seasonal stage has been studied in tomato (Maggio et al., 2007b). Experimental evidence suggests that at salinity higher than $2.5 \mathrm{dS} \mathrm{m}^{-1}$ (the tolerance threshold for tomato - Maas and Hoffman, 1977), a second physiological threshold (EC of $9.6 \mathrm{dSm}^{-1}$, corresponding to $88.5 \mathrm{mM} \mathrm{Cl}^{+}$) may activate a functional metabolic shift between different adaptation mechanisms. Physiologically, this transition is likely mediated by the abscisic acid (ABA) level, which at moderate stress (before the second stress threshold) is responsible for the control of short-term adaptation processes such as stomatal regulation and cellular homeostasis (Wilkinson and Davies, 2002). At advanced salinization (after the second tolerance threshold), higher ABA tissue concentrations may be involved in the control of organ adaptation processes, which will eventually lead to structural changes, including functional modifications of the root-to-shoot ratio (Maggio et al., 2007b).

\section{Functional morphologies in stress adaptation}

Genetic engineering for improved plant salt tolerance has mostly focused on downstream components of stress adaptation, namely ion exclusion/compartmentation and osmolytes accumulation (Maggio et al., 2001; Bressan et al., 2008). Less explored have been many morphological traits that could also be important in stress adaptation, including root and stomatal features. Unequivocal data on root architectures/morphologies that can benefit stress adaptation in saline environments are currently unavailable. Unlike drought stressed plants that generally expand their root systems (Cuartero and Fernàndez-Muñoz, 1999), salt stressed plants do not seem to respond to the same stimuli. Cabbage plants exposed to comparable levels of saline and drought stresses, in terms of soil water potentials, decreased their shoot/root ratio much less in the former compared to the latter (Maggio et al., 2005). It has been argued that large root/shoot ratios may be detrimental in saline environments since they would enhance the accumulation of toxic ions into the shoot and consequently anticipate the onset of the salt tolerance threshold (Dalton et al., 1997; Munns, 2002). In line with this view, it has been demonstrated in citrus that a reduced root-toshoot ratio may improve salinity tolerance (Moya et al., 1999). As previously discussed, structural modifications such as the control of shoot vs. root growth should be seen as part of a dynamic adaptation process in which plant physiological/metabolic responses evolve in parallel with plant development, soil salinization and atmospheric parameters throughout the growth season (Maggio et al., 2004; 2005). In spite of a large number of genes that are know to affect root morphologies, these concepts have not been confirmed or negated in plant model systems or different crops through gain- or loss-of-function experiments (Maggio et al., 2001; Morant et al., 2010).

Another trait in salinity tolerance, which has not received sufficient attention, is the stomatal control of transpirational water fluxes. Nontranspiring plants (or plants with a reduced transpiration rate) may overcome transitory salinity stress partly because the uploading of toxic ions to the shoot will be restricted and the oncoming of toxicity levels in photosynthesizing tissues will be delayed. Reduced transpiration due to low stomatal conductance will also reduce $\mathrm{CO}_{2}$ uptake, however. Plants with closed stomata may tolerate hypersomotic stress but they will not grow (Maggio et al., 2003b). During transitory stress events (midday water stress), a prompt stomatal closure may preserve tissue turgidity and prevent wilting. However, under permanent stresses, such as those caused by repeated saline irrigation or salinized soils, the control of stomatal aperture may be not an effective target to improve plant growth and yield. In vitro isolation of Arabidopsis mutants with increased salinity tolerance confirmed this tolerance-growth physiological trade-off. Mutants with a nonfunctional 9-cis-epoxicarotenoid dioxygenase (NCED) had a reduced level of stress-inducible $\mathrm{ABA}$. nced plants were able to germinate and grow in Petri plates under saturated atmosphere but were hypersensitive to salinity in greenhouse, due to their inability to close their stomata (Ruggiero et al., 2004). It has been demonstrated in non-stressed plants that overexpression of NCED may increase the tissues ABA concentration and decrease stomatal conductance without affecting $\mathrm{CO}_{2}$ assimilation and biomass accumulation (Thompson et al., 2007). While the $N C E D$ mediated stomatal regulation was proven to improve water use efficiency in non-stressed plants, its effect remains elusive respect to stress tolerance.

$\mathrm{ABA}$ is a major player in the control of plant stress adaptation, however it is only one component of an orchestrated hormonal control (Ross and Neill; 2001; Nemhauser et al., 2006). Other hormones are involved in the fine regulation of plant growth vs. adaptation that may have important practical implications in terms of yield and product quality (Weiss and Ori, 2007). Once again, the relative role of different hormones may be more or less important respect to both the level of stress experienced and the developmental stage. In tomato, different levels of endogenous $\mathrm{GA} 3$ and $\mathrm{ABA}$ on water fluxes may reduce or enhance plant salt tolerance (Maggio et al., 2010). It is therefore important to consider the actual level of stress to which crops are exposed since the control of hormonal balance, via genetic engineering or chemical treatments, may have positive effects at low and moderate salinity whereas it may have undesirable effects at moderate to high salinity.

The modulation of ABA levels to overcome moderate and/or transitory stresses could still find practical applications in greenhouse cultivation (De Pascale et al., 2003b; Maggio et al., 2010) where it is possible to adapt the environment to the actual plants needs. In principle, climatic control of the VPD and physiological control of stomatal conductance may be adjusted in order to uncouple water loss and $\mathrm{CO}_{2}$ uptake. This would consent to improve WUE and/or stress tolerance in controlled environments (De Pascale and Maggio, 2008).

More recently, stomatal traits have been proven to critically affect WUE. In absence of stress, it has been demonstrated that low stomatal density reduces transpirational water fluxes (Zhang et al., 2008) and improves water use efficiency (Masle et al., 2005).

\section{Interaction with other abiotic/biotic stressors}

The co-existence of multiple stresses is common in nature. Typically, in Mediterranean environments drought, heat and saline stress overlap. In addition, plants that suffer abiotic stresses are more susceptible to pathogens/pests attacks, which will further exacerbate damages and 
eventually compromise the final yield (Cheong et al., 2002; Xiong and Yang, 2003; Bostok, 2005).

Although there is a great variability of plant stress response to diverse cultural environments, the simultaneous occurrence of multiple stresses adds an extra level of complexity for the identification of field stress tolerance mechanisms. In this respect, comparative analysis of drought and salt stress responses may reveal physiological specificities and important practical implications. Celery is a relatively salt tolerant species that can be irrigated with saline water (up to $8.5 \mathrm{dS}$ $\mathrm{m}^{-1}$ ) with acceptable yield losses. Nevertheless, celery plants exposed to a level of water stress that is comparable, in terms of soil water potential to a respective saline stress, are unable to effectively cope with it (De Pascale et al., 2003a). We do not know if such response is a general one or specific to some species. However, it indicates that plant responses to drought and saline stress can be only partially superimposed (De Pascale et al., 2007). This may have important agronomic implications since the specific physiological response will determine the economic threshold based on which decisions on irrigating or not with saline water may be taken (i.e. choosing to expose plants either to moderate salt stress or to moderate water stress). Similar studies conducted in Southern Italy with pepper have indicated that an ECw of 4.4 $\mathrm{dS} \cdot \mathrm{m}^{-1}$ is a critical economic threshold for saline irrigation of this species (De Pascale et al., 2003c).

From a different perspective, it is worth emphasizing that molecular/physiological responses to diverse stresses may also overlap and confer cross tolerance, if potentiated. A few examples exist in the literature on multiple tolerances to different abiotic stresses. Overexpression of transcription factors has been proven to confer simultaneous tolerance to salinity, drought and freezing (Kasuga et al., 2004). Molecular components that control both biotic and biotic stress responses have been identified, also. Overproduction of osmotin in potato (Liu et al., 1994) and tomato (Goel et al., 2010) conferring tolerance to Phytoptora infestans and osmotic stress, respectively, is a classical example of this kind. Broad tolerance to biotic and abiotic stresses can be achieved by overexpressing transcription factors that have been shown to coordinately control the function of multiple stress responsive genes (Agarwal et al., 2006; Oh et al., 2007; Takumi et al., 2008). Additional examples include the function of secondary metabolites. In tomato, overexpression of prosystemin confers tolerance to afid attacks (Corrado et al., 2007) and salinity (Orsini et al., 2010a). Prosystemin transgenic tomato plants have been shown to perceive a less stressful environment when exposed to saline stress, indicating that a constitutive activation of wound responses, mediated by high prosystemin levels, can pre-adapt plants to further stresses.

The partial stomatal closure often presented by Mediterranean crops, including those of salinized coastal regions, is detrimental for achieving the maximum potential yield. However, it may protect agricultural crops from other environmental stressors. Phytotoxic levels of ozone (03) concentrations have been documented across Europe (Fagnano and Maggio, 2008b; Fagnano et al., 2009). These levels are much higher in Italy (Forlani et al., 2005; Fagnano and Maggio 2008a), Greece (Saitanis, 2008) and Spain (Gimeno et al., 1994) compared to NorthCentral Europe (EEA, 1996; 2003) and are likely to further increase in the years to come (Sitch et al., 2007). Since ozone enters into the plant through the stomata, the variability of plant response to ozone exposure depends on a number of factors that affect stomatal conductance. Experiments carried out in open top chambers (OTC) (Fagnano et al., 2004) at the University of Naples Federico II have documented reduced ozone damages in salt stressed plants (Maggio et al., 2007a; Maggio et $a l ., 2009 \mathrm{~b})$. This partial protection was associated to a reduced stomatal conductance caused by salt stress and, possibly, to the production of antioxidant molecules that is also salt-stress induced and further counteracts ozone damages (Wellburn and Wellburn, 1996; Ranieri et al., 2000; Maggio et al., 2007a; Maggio and Fagnano, 2008). These observa- tions have raised a need for revising current models for predicting crop ozone damages, since these rely on plant response functions based on ozone exposure (Fuhrer et al., 1997) rather than uptake, which may conceivably provide more reliable information on the actual toxicity levels (Fiscus et al., 2005; Pleijel et al., 2007).

\section{Effects on product quality}

The effects of salinity on quality parameters of the commercial products are less known respect to those on yield. Nevertheless, many highnutritional value secondary metabolites with acknowledged properties in the prevention of important human diseases, such as cancer and cardiovascular pathologies, accumulate in fresh fruits and vegetables in response to salinity and other environmental stresses (De Pascale $e t$ al., 2001). Tomato yield can be reduced to $50 \%$ at $8 \mathrm{dS} \mathrm{m}^{-1}$ (Maggio et al., 2004), yet irrigation with saline water can significantly improve both sugar and organic acid content of cherry tomatoes (De Pascale $e t$ al., 2007) and the flavour of processed tomatoes (Mitchell et al., 1991). Contrasting results have been reported for ascorbic acid, another high value metabolite, whose levels have been shown to increase (Petersen et al., 1998) or decrease (Dumas et al., 2003) in response to water stress and salinity, respectively. A 60\% ascorbic acid increase has been found in tomato fruits exposed at $\mathrm{EC}_{\mathrm{w}}$ of $15 \mathrm{dS} \mathrm{m}^{-1}$. Due to the involvement of ascorbic acid in several metabolic processes, its synthesis under stress may also depend on the interaction with other factors such as nitrogen availability (De Pascale et al., 2001).

Dry matter, soluble solids and titrable acidity have been reported to increase with salinity, also (Mitchell et al., 1991). These are all highly desirable qualities for the processed tomato industry. In addition, exposure to moderate salinity may also contribute to maintain low nitrates levels as a result of competition with $\mathrm{Cl}^{-}$. The increased concentration of total soluble solids in salinized plants is generally associated to a reduced water content, accumulation of ions and ex novo synthesis of organic molecules that in hyperosmotic environments have multiple functions, including osmotic adjustment and sequestration of reactive oxygen species. The increased acidity reported for many vegetables grown in saline environment, including eggplant (Savvas and Lenz, 1996), tomato (Kafkafi et al., 1982), melon (Feigin et al., 1987) and cucumber (Martinez and Cerdá, 1989) has been associated to the production of organic acids that typically accumulate under stress.

One side-effect of salinization is micronutrient deficiency that can derive from both soil alkalinisation and ions competition (Grattan and Grieve, 1999). Salt stress induced micronutrient deficiency may cause abnormal plant growth and irregular fruit development. Potassium (K), copper $(\mathrm{Cu})$ and zinc $(\mathrm{Zn})$ deficiencies have been reported in tomato exposed to salinity (Maggio et al., 2004).

Accumulation of functional molecules and ion partitioning has to be considered also respect to the commercial plant organs. In cauliflower, it was observed a significant accumulation of $\mathrm{Na}^{+}$and $\mathrm{Cl}^{-}$ions in the leaves, whereas the concentration of nitrogen $(\mathrm{N}), \mathrm{K}$ and $\mathrm{P}$ was higher in the heads (De Pascale et al., 2005). The head concentration of $\mathrm{Na}^{+}$ and $\mathrm{Cl}^{-}$was relatively higher in broccoli compared to cauliflower, indicating that different ion transports and accumulation mechanisms may exist in plants belonging to the same gender, yet characterized by different morphology. This may have important implications in the assessment of stress effects and overall definition of the nutritional profile of commercial products (De Pascale et al., 2005). Stress induced ion accumulation and partitioning may explain specific responses between different species. Cauliflowers accumulate more $\mathrm{Ca}^{2+}$ than broccoli in response to saline stress. This may protect cauliflower plants from tipburn and premature leaf senescence, which are in contrast relatively frequent in broccoli plants. Similarly, $\mathrm{Ca}^{2+}$ deficiencies may cause product quality decay in lettuce, endive and fennel (De Pascale and Barbieri, 1995). 
Effects of salt stress on ion uptake and accumulation have been observed for sulphur (S) also. Cauliflower head concentrations of $\mathrm{S}$ increase in response to salinity, whereas they do not change in leaves. A moderate increase has also been observed in broccoli (De Pascale $e t$ $a l ., 2005)$. Sulphur is an important precursor of glucosinolates and isothiocyanates, whose demonstrated anticarcinogenic activity contributes to the nutritional value of brassica species (Barbieri et al., 2008). In some cases, analysis of ion partitioning in different organs may reveal important redistribution mechanisms with significant physiological consequences. In carrots, $\mathrm{N} \mathrm{Na}^{+}$and $\mathrm{Cl}^{-}$concentrations of leaves and roots were doubled within the range of electrical conductivity of the saturated-soil extract (EC) between 1.9 and $4.2 \mathrm{dS} \mathrm{m}^{-1}$ without any significant distinction between the two organs (De Pascale and Barbieri, 2000). In contrast, $\mathrm{Na}^{+}$and $\mathrm{Cl}^{-}$concentrations of stressed radish plants irrigated with $8.5 \mathrm{mM}$ L-proline increased in hypocotils and decreased in leaves (Maggio et al., 2009a). It is not understood if the effect of proline treatment on root/shoot ions distribution can be generalized or it is peculiar to radish plants and/or hypertrophic root systems in general. In the latter case, radish and similar plants could be used as models to understand the dynamics of organ ions partitioning in plants exposed to saline stress. An enlarged (hypertrophic) root system may be functional to preserving aboveground edible parts from salt damages. Genes that regulate root development have been isolated and can be transferred via genetic engineering to test their function in stress tolerance/adaptation (Maggio et al., 2001; Morant et al., 2010).

A mild salt stress may also improve both lypophilic and hydrophilic antioxidant activities. Exposure to moderate salinity $\left(4.4 \mathrm{dS} \mathrm{m}^{-1}\right)$ can increase up to $40 \%$ the concentration of carotenoids in tomato fruits (De Pascale et al., 2001). This is mainly due to enhanced lycopene content, whose biosynthesis is activated under stress. However, the response of antioxidants metabolic pathways largely depends on the level of stress exposure and other cultural/environmental factors.

\section{Conclusions}

In this short review we attempted to highlight some aspects of cropsalinity interactions, mainly associated to different forms of salinization, which may occur in Mediterranean environments. These may range from over-salinized lands of coastal areas, where profound modifications of the soils physicochemical properties may lead to land abandonment, to balanced agro-ecosystems in which moderate salinization contributes to guarantee high value productions (see tomatoes of Pachino area - Sicily). Additional specificities of Mediterranean areas include: i) greenhouse cultivations, for which modifications of climatic parameters and/or root/substrate interactions (hydroponics) may contribute to cope with saline stress; ii) overlaps with other abiotic stress such as high temperature, photoinhibition, anoxia (in sodic soils), atmospheric pollutants $\left(\mathrm{O}_{3}\right)$ and biotic stresses, including pathogen and pest attacks; iii) dynamic interactions between plant development and transitory/permanent soil salinization; iv) exposure to seasonal salinization in irrigated spring/summer crops vs. residual soil salinization in fall-winter non-irrigated crops. All these conditions call for a careful assessment of those physiological mechanisms that may have functional priorities to overcome salt stress in specific agricultural conditions. In this respect, major physiological processes that control tolerance levels, namely water/ion homeostasis, hormone regulation and metabolic adjustment, growth control and injury control should be re-examined in specific cultural contexts to i) bring current knowledge to a new level of application and ii) identify novel targets to improve field salinity tolerance. Significant progress in this field can be expected from a closer interaction between molecular engineers and crop physiologists.

\section{References}

Agarwal P.K., Agarwal P., Reddy M.K., Sopory S.K. 2006. Role of DREB transcription factors in abiotic and biotic stress tolerance in plants. Plant Cell Rep. 25: 1263-74.

Amzallag G.N. 2002. The adaptive potential of plant development: evidence from the response to salinity. In: A. Lauchli and U. Luttge (eds.) Salinity: Environment-Plants-Molecules. Kluwer Academic Publ., The Netherlands, pp 291-312.

Barbieri G., De Pascale S., Sifola M.I., 1994. Effetti della frequenza di irrigazione sulle funzioni di risposta produttiva della melanzana (Solanum melongena L.) alla salinità. Riv. Agron. 3:235-246.

Barbieri G., Pernice R., Maggio A., De Pascale S., Fogliano V., 2008. Glucosinolates profile of Brassica rapa L. subsp Sylvestris L. Janch. var. esculenta. Hort. Food Chem. 107:1687-1691.

Bostok R.M., 2005. Signal crosstalk and induced resistance: straddling the line between cost and benefit. Annu. Rev. Phytopathol. 43:545580 .

Bressan R.A., Bohnert H.J., Hasegawa P.M., 2008. Genetic engineering for salinity stress tolerance. Adv. Plant Biochem. Mol. Biol. 1:347384.

Bressan R.A., Bohnert H.J., Zhu J.K., 2009. Perspective abiotic stress tolerance: from gene discovery in model organisms to crop improvement. Mol. Plant 2:1-2.

Cheong Y.H., Chang H.S., Gupta R., Wang X., Zhu T., Luan S., 2002. Transcriptional profiling reveals novel interactions between wounding, pathogen, abiotic stress, and hormonal responses in Arabidopsis. Plant Physiol. 129:661-677.

Chinnusamy V., Jagendorf A., Zhu J.K., 2005. Understanding and improving salt tolerance in plants. Crop Sci. 45:437-448.

Chinnusamy V., Zhu J.K., 2009. Epigenetic regulation of stress responses in plants. Curr. Opin. Plant Biol. 12:133-139.

Corrado G., Sasso R., Pasquariello M., Iodice L., Carretta A., Cascone P., Ariati L., Digilio M.C., Guerrieri E., Rao R., 2007. Systemin regulates both systemic and volatile signalling in tomato plants. J. Chem. Ecol. 33:669-681.

Cuartero J., Fernàndez-Muñoz R., 1999. Tomato and salinity. Sci. Hort. 78: 83-125.

Dalton F.N., Maggio A., Piccinni G., 1997. Effect of root temperature on plant response functions for tomato: comparison of static and dynamic salinity stress indices. Plant Soil 192:307-319.

Dalton F.N., Maggio A., Piccinni G., 2000. Simulation of shoot chloride accumulation, separation of physical and biochemical processes governing plant salt tolerance. Plant Soil 219:1-11.

Dalton F.N., Maggio A., Piccinni G., 2001. Assessing the effect of solar radiation on plant salt tolerance as defined by the static and dynamic indices. Plant Soil 229:189-195.

De Pascale S., Barbieri G., 1995. Effects of soil salinity from long-term irrigation with saline-sodic water on yield and quality of winter vegetable crops. Sci. Hort. 64:145-157.

De Pascale S., Barbieri G., 1997. Effect of soil salinity and top removal on growth and yield of broadbean as a green vegetable. Sci. Hort. $71: 147-165$.

De Pascale S., Barbieri G., 2000. Yield and quality of carrot as affected by soil salinity from long-term irrigation with saline water. Acta Hort. 357:621-628.

De Pascale S., Maggio A., 2008. Plant stress management in semiarid greenhouse. Acta Hort. 797:205-215.

De Pascale S., Maggio A., Barbieri G., 2005. Soil salinization affects growth, yield and mineral composition of cauliflower and broccoli. Eur. J. Agron. 23:254-264.

De Pascale S., Maggio A., Fogliano V., Ambrosino P., Ritieni A., 2001. Irrigation with saline water improves carotenoids content and 
antioxidant activity of tomato. J. Hort. Sci. Biotec. 76:447-453.

De Pascale S., Maggio A., Ruggiero C., Barbieri G., 2003a. Growth, water relations, and ion content of field grown celery under saline irrigation (Apium graveolens L. var. dulce [Mill.] pers.). J. Amer. Soc. Hort. Sci. 128: 136-143.

De Pascale S., Martino A., Raimondi G., Maggio A., 2007. Comparative analysis of water and salt stress-induced modifications of quality parameters in cherry tomato. J. Hort. Sci. Biotec. 82:283-289.

De Pascale S., Raimondi G., Martino A., Barbieri G., 2003b. Water relations and abscisic acid content in tomato as affected by osmotic stress. Acta Hort. 609:89-95.

De Pascale S., Ruggiero C., Barbieri G., Maggio A., 2003c. Physiological response of pepper (Capsicum annuum L.) to salinity and drought. J. Amer. Soc. Hort. Sci. 128:48-54.

Dumas Y., Dadomo M., Di Lucca G., Grolier P., 2003. Effects of environmental factors and agricultural techniques on antioxidant content of tomatoes. J. Sci. Food Agric. 83: 369-382.

EEA 1996. Air Pollution by Ozone in the European Union. Eur. Environ. Agency. Topic Centre on Air Quality, Copenhagen, Denmark.

EEA 2003. Air pollution by ozone in Europe in summer 2003. Overview of exceedances of EC ozone threshold values during the summer season april-august 2003 and comparisons with previous years. Eur. Environ. Agency. Topic Centre on Air Quality, Copenhagen, Denmark.

Fagnano M., Maggio A., 2008a. Ozone damages to Italian crops: environmental constraints. It. J. Agron. 3:7-12.

Fagnano M., Maggio A., 2008b. Ozone risk assessment for European vegetation. It. J. Agron. 3 3-6.

Fagnano M., Maggio A., Fumagalli I., 2009. Crops responses to ozone in Mediterranean environments. Environ. Pollut. 157:1438-1444.

Fagnano M., Merola G., Forlani A., Postiglione L., Fuhrer J., 2004. Monitoring yield loss from ozone pollution in a Mediterranean environment: a comparison of methods. Water Air Soil Pollut. 155:383-398.

Feigin A., Rylski I., Meiri A., Shalevet J., 1987. Response of melon and tomato plants to chloride-nitrate ratios in saline nutrient solutions. J. Plant Nutr. 10:1787-1794.

Fiscus E.L., Booker F.L., Burkey K.O., 2005. Crop responses to ozone: uptake, modes of action, carbon assimilation and partitioning. Plant Cell Environ. 28:997-1011.

Flowers T.J., 2004. Improving crop salt tolerance. J. Exp. Bot. 55:307319.

Forlani A., Merola G., Fagnano M., 2005. Ozone effects on vegetation in three different localities of Campania region. Fres. Environ. Bull. 14:478-483.

Fuhrer J., Skarby L., Ashmore M.R., 1997. Critical levels for ozone effects on vegetation in Europe. Environ. Pollut. 97:91-106.

Gimeno B.S., Velissariou D., Schenone G., Guardans G., 1994. Ozone effects on the Mediterranean region: an overview. In: J. Fuhrer and B. Acherman (eds.). Critical Level for Ozone. Schrifttenreihe der FAC 16, Liebefeld-Bern, Switzerland, pp 122-136.

Goel D., Singh A.K., Yadav V., Babbar S.B., Bansal K.C., 2010. Overexpression of osmotin gene confers tolerance to salt and drought stresses in transgenic tomato (Solanum lycopersicum L.). Protoplasma 245:133-41.

Grattan S.R., Grieve C.M., 1999. Salinity-mineral nutrient relations in horticultural crops. Sci. Hort. 78:127-57.

Hachicha M., Cheverry C., Mhiri A., 2000. The impact of longterm irrigation on changes of ground water level and soil salinity in northern Tunisia. Arid Soil Res. Rehab. 14:175-182.

Hasegawa P.M., Bressan R.A., Zhu J.K., Bohnert H.J., 2000. Plant cellular and molecular responses to high salinity. Annu. Rev. Plant Physiol. Plant Mol. Biol. 51 463-499.

Inan G., Zhang Q., Li P., Wang Z., Cao Z., Zhang H., Zhang C., Quist
T.M., Goodwin S.M., Zhu J., Shi H., Damsz B., Charbaji T., Gong Q., Ma S., Fredricksen M., Galbraith D.W., Jenks M.A., Rhodes D., Hasegawa P.M., Bohnert H.J., Joly R.J., Bressan R.A., Zhu J.K., 2004. Salt cress. A halophyte and cryophyte Arabidopsis relative model system and its applicability to molecular genetic analyses of growth and development of extremophiles. Plant Physiol. 135:17181737.

Kafkafi U., Valoras N., Letey J., 1982. Chloride interaction with nitrate and phosphate nutrition in tomato (Lycopersicon esculentum L.). J. Plant Nutr. 5:1369-85.

Karakas B., Ozias-Akins P., Stushnoff C., Suefferheld M., Rieger M., 1997. Salinity and drought tolerance of mannitol-accumulating transgenic tobacco. Plant Cell Environ. 20:609-16.

Kasuga M., Liu Q., Miura S., Yamaguchi-Shinozaki K., Shinozaki K., 1999. Improving plant drought, salt, and freezing tolerance by gene transfer of a single stress-inducible transcription factor. Nature Biotec. 17:287-291.

Kasuga M., Miura S., Shinozaki K., Yamaguchi-Shinozaki K., 2004. A combination of the Arabidopsis DREB1A gene and stress-inducible rd29A promoter improved drought- and low-temperature stress tolerance in tobacco by gene transfer. Plant Cell Physiol. 45:346-350.

Katerji N., van Hoorn J.W., Hamdy A., Bouzid N., El-Sayed Mahrous S., Mastrorilli M., 1992. Effect of salinity on water stress, growth and yield of broadbeans. Agric. Water Manag. 21:107-117.

Katerji N., van Hoorn J.W., Hamdy A., Mastrorilli M. 2000. Salt tolerance classification of crops according to soil salinity and to water stress day index. Agric. Water Manag. 43:99-109

Liu D, Raghothama KG, Hasegawa PM, Bressan RA., 1994. Osmotin overexpression in potato delays development of disease symptoms. Proc. Natl. Acad. Sci. USA. 91:1888-92.

Lutts S., Kinet J.M., Bouharmont J., 1995. Changes in plant response to $\mathrm{NaCl}$ during development of rice (Oryza sativa L.) varieties differing in salinity resistance. J. Exp. Bot. 46:1843-1852.

Maas E.V., Grattan S.R., 1999. Crop yields as affected by salinity. In: R.W. Skaggs and J. van Schilfgaarde (eds.).: Agricultural drainage. Agron. Monogr. 38. Amer. Soc. Agron., Madison, WI, USA, pp 55-108.

Maas E.V., Hoffman G.J., 1977. Crop salt tolerance, current assessment. J. Irrig. Drain. Div. 103:115-134.

Maggio A., Barbieri G., Raimondi G., De Pascale S., 2010. Contrasting effects of GA3 treatments on tomato plants exposed to increasing salinity. J. Plant Growth Regul. 29:63-72.

Maggio A., Bressan R.A., Ruggiero C., Xiong L., Grillo S. 2003a. Salt tolerance: placing advances in molecular genetics into a physiological and agronomic context. In: L. Sanità di Toppi and B. PawlikSkowrońska (eds.). Abiotic stresses in plants. Kluwer Academic Publ., Dordrecht, The Netherlands, pp 53-69.

Maggio A., Dalton F.N., Piccinni G., 2002. The effects of elevated carbon dioxide on static and dynamic indices for tomato salt tolerance. Eur. J. Agron. 16:197-206.

Maggio A., De Pascale S., Angelino G., Ruggiero C., Barbieri G., 2004. Physiological response of tomato to saline irrigation in long-term salinized soils. Eur. J. Agron. 21:149-159.

Maggio A., De Pascale S., Barbieri G., 2009a. Designing a greenhouse plant: novel approaches to improve resource use efficiency in controlled environments. Acta Hort. 801:1235-1242.

Maggio A., De Pascale S., Fagnano M., Barbieri G., 2007a. Can salt stress-induced physiological responses protect tomato crops from ozone damages in Mediterranean Environments? Eur. J. Agron. 26:454-461.

Maggio A., De Pascale S., Ruggiero C., Barbieri G., 2005. Physiological response of field-grown cabbage to salinity and drought stress. Eur. J. Agron. 23:57-67.

Maggio A., Fagnano M., 2008. Ozone damages to Mediterranean crops: physiological responses. It. J. Agron. 3:13-20. 
Maggio A., Hasegawa P.M., Bressan R.A., Consiglio M.F., Joly R.J., 2001. Unraveling the functional relationship between root anatomy and stress tolerance. Aust. J. Plant Physiol. 28:999-1004.

Maggio A., Joly R.J., Hasegawa P.M., Bressan R.A. 2003b. Can the quest for drought tolerant crops avoid Arabidopsis any longer? In: S.S. Goyal, S.K. Sharma and D.W. Rains (eds.). Crop production in saline environments: global and integrative perspectives. The Food Products Press, Binghamton, NY, USA, pp 99-129.

Maggio A., Quaglietta Chiarandà F., Cefariello R., Fagnano M., 2009b. Responses to ozone pollution of alfalfa exposed to increasing salinity levels. Environ. Pollut. 157:1445-1452.

Maggio A., Raimondi G., Martino A., De Pascale S., 2007b. Salt stress response in tomato the salinity tolerance threshold. Env. Exp. Botany 59:276-282.

Maggio A., Zhu J.K., Hasegawa P.M., Bressan R.A., 2006. Osmogenetics: Aristotle to Arabidopsis. Plant Cell 18:1542-1557.

Martinez V., Cerdá A., 1989. Influence of $\mathrm{N}$ source on rate of $\mathrm{Cl}, \mathrm{N}, \mathrm{Na}$, $\mathrm{K}$ uptake by cucumber seedlings grown in saline conditions. J. Plant Nutr. 12:971-983.

Masle J., Gilmore S.R., Farquhar G.D., 2005. The ERECTA gene regulates plant transpiration efficiency in Arabidopsis. Nature 436:866870.

Mitchell J. P., Shennan C.,Grattan S. R., May D.M., 1991. Tomato fruit yields and quality under water deficit and salinity. J. Am. Soc. Hort. Sci. 116:215-221.

Morant M., Ekstrøm C., Ulvskov P., Kristensen C., Rudemo M., Olsen C.E., Hansen J., Jørgensen K., Jørgensen B., Møller B.L., Bak S., 2010. Metabolomic, transcriptional, hormonal, and signalling cross-talk in Superroot2. Mol. Plant 3:192-211.

Moya J.L., Primo-Millo E., Talon, M., 1999. Morphological factors determine salt tolerance in citrus seedlings: the shoot to root ratio modulates passive root uptake of chloride ions and their accumulation in leaves. Plant Cell Environ. 22:1425-1433.

Munns R., 2002. Comparative physiology of salt and water stress. Plant Cell Environ. 25:239-250.

Munns R., 2005. Genes and salt tolerance: bringing them together. New Phytol. 167:645-663.

Nemhauser J.L., Hong F.X., Chory J., 2006. Different plant hormones regulate similar processes through largely nonoverlapping transcriptional responses. Cell 126:467-475.

Oh S.J., Kwon C.W., Choi D.W., Song S.I., Kim J.K., 2007. Expression of barley HvCBF4 enhances tolerance to abiotic stress in transgenic rice. Plant Biotec. J. 5:646-56.

Orsini F., Cascon P., De Pascale S., Barbieri G., Corrado G., Rao R., Maggio A., 2010a. Systemin-dependent salinity tolerance in tomato: evidence of specific convergence of abiotic and biotic stress responses. Physiol. Plant. 138:10-21.

Orsini F., Paino D’Urzo M., Inan G., Serra S., Oh D.H., Mickelbart M.V., Consiglio F., Li X., Jeong J.C., Yun D.J., Bohnert H.J., Bressan R.A., Maggio A., 2010b. A comparative study of salt tolerance parameters in 11 wild relatives of Arabidopsis thaliana. J. Exp. Bot. 61:37873798.

Pardo J.M., 2010. Biotechnology of water and salinity stress tolerance. Curr. Opin. in Biotec. 21:185-196.

Pardossi A., Malorgio F., Oriolo D., Gucci R., Serra G., Tognoni F., 1998. Water relations and osmotic adjustment in Apium graveolens during long-term $\mathrm{NaCl}$ stress and subsequent relief. Physiol. Plant. 102369-376.

Petersen K.K., Willumsen J., Kaack K., 1998. Composition and taste of tomatoes as affected by increased salinity and different salinity sources. J. Hort. Sci. Biotec. 73:205-215.

Pleijel H., Danielsson H., Emberson L., Ashmore M.R. Mills, G., 2007. Ozone risk assessment for agricultural crops in Europe: further development of stomatal flux and flux-response relationships for
European wheat and potato. Atm. Environ. 41:3022-3040.

Quintero F.J., Ohta M., Shi H., Zhu J.K., Pardo J.M., 2002. Reconstitution in yeast of the Arabidopsis SOS signalling pathway for Na+ homeostasis. Proc. Natl. Acad. Sci. USA 99:9061-9066.

Ranieri, A., Petacco, F., Castagna, A., Soldatini, G.F., 2000. Redox state and peroxidase system in sunflower plants exposed to ozone. Plant Sci. 159:159-167.

Rhoades J.D., Kandiah A., Mashali A.M., 1992. The use of saline waters for crop production. FAO, Roma, Italy.

Ross J., O'Neill D., 2001. New interactions between classical plant hormones. Trends Plant Sci. 6:2-4.

Royal Society, 2009. Reaping the benefits: science and the sustainable intensification of global agriculture. The Royal Society, London, UK. Available at: http://royalsociety.org/Reapingthebenefits/

Rozema J., Flowers T., 2008. Crops for a salinized world. Science 322:1478-1480.

Ruggiero B., Koiwa H., Manabe Y., Quist T.M., Inan G., Saccardo F., Joly R.J., Hasegawa P.M., Bressan R.A., Maggio A., 2004. Uncoupling the effects of $A B A$ on plant growth and water relations: analysis of sto1/nced3, ABA deficient salt stress tolerant mutant in Arabidopsis thaliana. Plant Physiol. 136:3134-3147.

Saitanis C., 2008. Tropospheric ozone: a menace for crops and natural vegetation in Greece. It. J. Agron. 3:71-77.

Sakamoto A., Alia H., Murata N., 1998. Metabolic engineering of rice leading to biosynthesis of glycinebetaine and tolerance to salt and cold. Plant Mol. Biol. 38:1011-1019.

Sakamoto A., Murata N., 2002. The role of glycinebetaine in the protection of plants from stress: clues from transgenic plants. Plant Cell Environ. 25:163-171.

Samis K., Bowley S., McKersie B., 2002. Pyramiding Mn-superoxide dismutase transgenes to improve persistence and biomass production in alfalfa. J. Exp. Bot. 53:1343-1350.

Savvas D., Lenz F. 1996. Influence of $\mathrm{NaCl}$ concentration in the nutrient solution on mineral composition of eggplants grown in sand culture. Angewandte Botanik 70:124-127.

Sheveleva E., Chmara W., Bohnert H.J., Jensen R.G., 1997. Increased salt and drought tolerance by D-ononitol production in transgenic Nicotiana tabacum L. Plant Physiol. 115:1211-1219.

Shi H., Lee B.H., Wu S.J., Zhu J.K., 2003. Overexpression of a plasma membrane $\mathrm{Na} / \mathrm{H}_{-}$antiporter improves salt tolerance in tolerance in rice are inversely modulated by an abscisic acid-Arabidopsis. Nature Biotec. 21:81-85.

Sitch S., Cox P.M., Collins W.J., Huntingford C., 2007. Indirect radiative forcing of climate change through ozone effects on the land-carbon sink. Nature 448:791-794.

Takumi S, Shimamura C, Kobayashi F., 2008. Increased freezing tolerance through up-regulation of downstream genes via the wheat CBF gene in transgenic tobacco. Plant Physiol. Biochem. 46:205-11.

Thompson A.J., Andrews J., Mulholland B.J., McKee J.M., Hilton H W., Horridge J.S., Farquhar G.D., Smeeton R.C., Smillie I.R., Black C.R., Taylor I.B., 2007. Overproduction of abscisic acid in tomato increases transpiration efficiency and root hydraulic conductivity and influences leaf expansion. Plant Physiol. 143:1905-1917.

United Nations, 2009. United Nations Population Information Network. Available at. www.un.org/popin/data.html

Weiss D., Ori N., 2007. Mechanisms of cross talk between gibberellin and other hormones. Plant Physiol. 144:1240-1246.

Wellburn F.A.M., Wellburn A.R., 1996. Variable patterns of antioxidant protection but similar ethene emission differences in several ozone-sensitive and ozone-tolerant plant selections. Plant Cell Environ. 19:754-760.

Wilkinson S., Davies W.J., 2002. ABA-based chemical signalling: the coordination of responses to stress in plants. Plant Cell Environ. 25: 195-210. 
Xiong L., Yang Y., 2003. Disease resistance and abiotic stress tolerance in rice are inversely modulated by an abscisic acid-inducible mitogen-activated protein kinase. Plant Cell 15:745-759.

Xue Z.Y., Zhi D.Y., Xue G.P., Zhang H., Zhao Y.X., Xia G.M., 2004. Enhanced salt tolerance of transgenic wheat (Tritivum aestivum L.) expressing a vacuolar $\mathrm{Na}^{+} / \mathrm{H}^{+}$antiporter gene with improved grain yields in saline soils in the field and a reduced level of leaf $\mathrm{Na}^{+}$. Plant Sci. 167:849-859.

Zhang H.X., Blumwald E., 2001. Transgenic salt-tolerant tomato plants accumulate salt in foliage but not in fruit. Nature Biotec. 19:765768.
Zhang H.X., Hodson J.N., Williams J.P., Blumwald E., 2001. Engineering salt-tolerant Brassica plants: characterization of yield and seed oil quality in transgenic plants with increased vacuolar sodium accumulation. Proc. Natl. Acad. Sci. USA 98:12832-12836.

Zhang L., Hu G., Cheng Y., Huang J., 2008. Heterotrimeric G protein alpha and beta subunits antagonistically modulate stomatal density in Arabidopsis thaliana. Dev. Biol. 324:68-75.

Zhu J.K., 2000. Genetic analysis of plant salt tolerance using Arabidopsis. Plant Physiol. 124:941-948.

Zhu J.K., 2002. Salt and drought stress signal transduction in plants. Annu. Rev. Plant Biol. 53:247-273. 